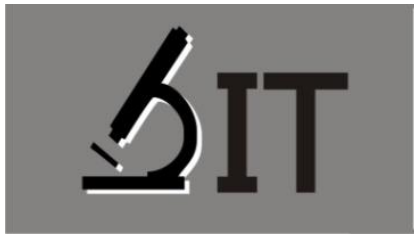

p-ISSN : 2597-8977

e-ISSN : 2597-8985

A. Fitriani Suryadi *)

STKIP Yapti Turatea Jeneponto

Sudarto

Universitas Negeri Makassar

Ramlawati

Universitas Negeri Makassar

*) Correspondence Author:

a.fitrianisuryadi3o@gmail.com
JIT 3 (2) (2020) 37-45

JURNAL IPA TERPADU

http://ojs.unm.ac.id/index.php/ipaterpadu

\section{PENGEMBANGAN HANDOUT PEMBELAJARAN IPA TERPADU TIPE WEBBED BERBASIS KONTEKSTUAL PESERTA DIDIK KELAS VIII TEMA MAKANAN}

Abstrak: Penelitian ini bertujuan untuk 1) menghasilkan handout pembelajaran IPA terpadu tipe webbed berbasis kontekstual di kelas VIII pada tema makanan, 2) untuk mengetahui respon peserta didik dan pendidik terhadap handout IPA terpadu tipe webbed berbasis kontekstual pada tema makanan, dan 3) untuk mengetahui peningkatan hasil belajar peserta didik dengan menggunakan handout pembelajaran IPA terpadu tipe webbed berbasis kontekstual pada tema makanan. Penelitian dilakukan dengan menggunakan metode research and development ( $R \& D)$ dan model penelitian pengembangan yang digunakan yaitu model four D (model 4-D). Uji coba produk menggunakan one group pretestposttest design, yang di laksanakan di SMPN 2 Majene kelas VIIIA tahun pelajaran 2016/2017 semester genap, dengan jumlah subyek 28 orang. Instrumen yang digunakan adalah lembar validasi, angket respon peserta didik, dan lembar tes hasil belajar. Hasil belajar diolah dengan menggunakan N-gain skor. Hasil penelitian menunjukkan bahwa: (1) handout pembelajaran IPA terpadu tipe webbed berbasis kontekstual pada tema makanan yang telah dikembangkan layak digunakan untuk pembelajaran berdasarkan penilaian dari validator dengan rata-rata perolehan nilai yaitu 3,4 berada pada kategori valid, (2) respon peserta didik dan pendidik terhadap handout IPA terpadu tipe webbed berbasis kontekstual pada tema makanan adalah Sangat Positif dengan rata-rata nilai yaitu $89 \%$ dan $94 \%$, dan (3) N-gain hasil belajar peserta didik yang dibelajarkan dengan menggunakan handout pembelajaran IPA terpadu tipe webbed dengan persentase penilaian 53,5\% yang menunjukkan peningkatan berada dalam kategori tinggi. Dapat disimpulkan handout pembelajaran IPA terpadu tipe webbed berbasis kontekstual pada tema makanan layak digunakan dalam pembelajaran IPA di sekolah.

Kata Kunci: Handout, IPA Terpadu Tipe Webbed.

Abstract: This study aimed to 1) produce Contextual Webbed Type Natural Sciences Learning Handout in Food Theme for the 8th grade students, 2) to describe how the students perceive the use of the handout, and 3) to explain the improvement made by the students by using the handout. This study was done by using Research and Development (R\&D) method. The development model was four D (4-D model). The product examination used one-group-pretest-posttest design and was held in class VIIIA of SMPN 2 Majene for second semester of academic year 2016/2017. The number of subjects was 28 students. The instruments of this study were validation sheet, response questionnaire and test sheet. The test result was analyzed by using $\mathrm{N}$-gain score. The result of the study showed that (1) Contextual Webbed Type Natural Sciences Learning Handout in Food Theme was worth using according to the validator ratings with average 
gain score 3,4 which is considered valid, (2) The response of the students and the teachers toward the handout was positive based on the questionnaire result which showed average score $89 \%$ and $94 \%$, and (3) Ngain test result of the students who were taught by using the handout was $53,5 \%$ in high category. To conclude with Contextual Webbed Type Natural Sciences Learning Handout in Food Theme was worth using in natural sciences teaching and learning process at school.

Keyword: Handout, Webbed Type Natural Sciences.

\section{PENDAHULUAN}

Saat ini hampir semua sekolah sudah memberlakukan kurikulum 2013. Dalam kurikulum 2013 materi pembelajaran IPA dibelajarkan secara terpadu, sehingga materi fisika, biologi, dan kimia disajikan secara terpadu. Pembelajaran IPA terpadu merupakan pendekatan yang mencoba menggabungkan beberapa materi yaitu fisika, kimia, dan biologi dalam pelaksanaannya tidak lagi terpisah-pisah dalam Panduan Pengembangan Pembelajaran IPA Terpadu yang diterbitkan (Depdiknas, 2013).

Kenyataan saat ini masih ada beberapa pendidik yang membelajarkan pembelajaran IPA sebagai bagian yang terpisah dalam arti, pembelajaran IPA tidak dilakukan secara terpadu. Pendidik yang memiliki latar belakang pendidikan biologi masih menekankan materi biologi dalam pembelajaran, begitupun halnya dengan pendidik yang memiliki latar belakang pendidikan kimia dan fisika lebih menekankan pada konten fisika dan kimia dalam proses pembelajaran.

Hasil observasi yang telah dilakukan beberapa sekolah menjelaskan bahwa, pendidik mata pelajaran IPA hanya menggunakan sumber belajar berupa buku paket. Dalam buku tersebut belum menyajikan IPA secara terpadu disebabkan karena materi fisika, kimia, dan biologi yang disajikan dalam buku masih secara terpisah dan belum ada keterkaitan satu dengan lainnya.

Oleh karena itu peneliti akan mengembangkan bahan ajar yaitu handout IPA terpadu pada tema makanan dari kajian kimia, biologi, dan fisika yang disajikan secara utuh. Tema makanan memiliki karekteristik yaitu perpaduan dari beberapa KD yang terkait dengan tema serta konsepnya berkaitan dalam semester dan kelas yang berbeda. Hal ini sesuai hasil penelitian Pentiwati, Atok and Tuti (2014) yang menyatakan bahwa proses belajar mengajar lebih efektif jika mengintergrasikan mata pelajaran kimia, biologi, dan fisika. Penelitian Akhtar and Akbar (2011) juga menyatakan bahwa penerapan dengan menggunakan bahan ajar secara terpadu di sekolah dapat meningkatkan efektivitas dan efisiensi proses pembelajaran.

Handout adalah bahan tertulis yang disiapkan oleh seorang pendidik untuk memperkaya pengetahuan peserta didik (Depdiknas, 2008). Prastowo (2014) menyatakan bahwa handout adalah bahan pembelajaran yang sangat ringkas. Bahan ini bersumber beberapa literatur yang relevan terhadap kompetensi dasar dan materi pokok yang diajarkan oleh peserta didik. Karakteristik dari handout yaitu memiliki materi yang lebih padat, sebagai media pengajaran yang lebih rinci tentang isi handout diberikan pada awal pelajaran.

Kelebihan dari handout IPA terpadu adalah 1) Sesuai tuntutan kurikulum 2013 yang menekankan pembelajaran IPA terpadu dalam pembelajaran fisika, kimia, dan biologi yang dalam pelaksanaannya tidak lagi terpisah-pisah melainkan menjadi satu kesatuan, 2) Isi materi pada handout yang kontekstual sehingga membangun pengetahuan peserta didik, dan 3) Handout yang dikembangkan merupakan bahan ajar cetak mudah digunakan peserta didik. Hal ini sesuai dengan hasil penilitian Nelson (2013) yaitu dengan menggunakan handout dalam proses pembelajaran peserta didik tidak mencatat lagi sehingga memiliki waktu yang lebih efisien.

Handout IPA terpadu menggunakan pembelajaran IPA tipe webbed karena dapat menentukan tema-tema yang menarik yang dekat dengan kehidupan peserta didik yang 
disesuaikan dengan situasi dan kondisi. Sedangkan tipe lainnya seperti integrated dan connected tidak dapat memilih tema dalam memadukan materi tetapi memilih terlebih dahulu KD yang beririsan (Fogarty, 1991). Sehingga hal tersebut menjadi pertimbangan peniliti dalam mengambil tipe webbed. Hasil penelitian Kurniasih (2015) menyatakan bahwa dengan menggunakan tipe webbed akan menumbuhkan keterampilan berpikir kritis peserta didik.

Kelebihan dari tipe webbed, meliputi 1) Penentuan tema disesuaikan minat peserta didik sehingga akan memotivasi peserta didik untuk belajar, 2) mudah dilakukan oleh pendidik yang belum berpengalaman, 3) memberikan kemudahan bagi peserta didik melihat kegiatan-kegiatan dan ide-ide berbeda yang terkait (Trianto, 2007). Hal ini sesuai dengan hasil penelitian sebelumnya yang dilakukan Kurniawati (Suliyanah and Qosyim, 2013) dengan menggunakan bahan ajar IPA terpadu tipe webbed akan meningkatkan hasil belajar peserta didik dan penelitian Husna (2015) menyatakan bahwa dengan menggunakan bahan ajar dengan model pembelajaran IPA terpadu tipe webbed meningkatkan hasil belajar peserta didik.

Model pengembangan yang akan digunakan dalam pengembangan handout pembelajaran IPA terpadu tipe webbed berbasis kontekstual adalah model 4-D. Model ini dipilih berdasarkan beberapa pertimbangan yaitu menggunakan pendekatan sistem dengan langka-langkah yang lengkap dan merancang pembelajaran secara lebih sistematis. Hal ini sesuai hasil penelitian Jaya (2014) bahwa perangkat pembelajaran biologi yang dikembangkan dengan model pengembangan 4-D memiliki validitas dengan kategori sangat valid dan layak digunakan. Pengembangan model 4D (four D model), yang terdiri dari 4 tahap. Keempat tahap tersebut adalah tahap pendifinisian (define), tahap perancangan (design), tahap pengembangan (development), dan tahap penyebaran (disseminate).

Adapun tujuan dari penelitian ini adalah sebagai berikut:

1) Mengetahui seberapa besar kevalidan handout IPA terpadu tipe webbed pada tema makanan yang telah dikembangkan

2) Mengetahui respon peserta didik dan pendidik terhadap bahan ajar handout IPA terpadu tipe webbed berbasis kontekstual pada tema makanan.

3) Mengetahui besarnya peningkatan hasil belajar peserta didik yang diajar dengan menggunakan handout IPA terpadu tipe webbed berbasis kontekstual pada tema makanan.

\section{METODE}

Jenis penelitian ini adalah penelitian pengembangan (Research and Development) dengan menggunakan model 4-D yang terdiri dari 4 tahap yaitu tahap pendifinisian (define), tahap perancangan (design), tahap pengembangan (development), dan tahap penyebaran (disseminate).

Melakukan uji coba di sekolah SMPN 2 Majene, dengan subjek peserta didik kelas VIIIA dengan jumlah peserta didik 28 orang. Waktu penelitian dilakukan pada semester ganjil tahun pelajaran 2016/2017. Instrumen penelitian yang digunakan adalah lembar validasi handout dan tes hasil belajar. Handout pembelajaran yang telah dihasilkan selanjutnya di-uji cobakan menggunakan desain pretest- posttest atau one group pretest-posttest design.

Analisis data yang digunakan dalam penelitian pengembangan ini adalah analisis deksriptif kuantatif. Analisi deksriptif kuantatif digunakan untuk mengolah data yang diperoleh melalui lembar validasi dan tes hasil belajar. Analisis hasil belajar menggunakan rumus $\mathrm{N}$-gain kemudian mencocokkan dengan kriteria $\mathrm{N}$-gain yaitu $0<\mathrm{N}<0,3$ kategori rendah, $0,3 \leq \mathrm{N} 0,7$ kategori sedang, dan $0,7 \leq \mathrm{N} \leq 1,0$ kategori tinggi. 


\section{HASIL DAN PEMBAHASAN}

Validasi handout dilakukan oleh pakar materi dan pakar media. Tabel 1 disajikan validasi terhadap pengembangan handout yang terdiri dari beberapa aspek yaitu format, bahasa dan tulisan, isi handout, ilustrasi, fisik, dan manfaat handout.

Nilai rata-rata hasil validasi pada Tabel 1 adalah 3, 4 tergolong kategori valid yaitu 2,5 $\leq X \leq 3,5$. Berdasarkan hasil validasi yang telah dilakukan pada pengembangan handout yang di kembangkan berada pada kategori valid dan sangat valid. Hal ini dapat dilihat dari 5 aspek kategori valid yang terdiri dari 1) format yang memiliki kategori valid dengan beberapa masukan oleh validator yaitu setiap KD harus memiliki indikator secara lengkap, 2) ilustrasi dalam handout memiliki kategori valid, dengan perbaikan yaitu perbaikan gambar yang kurang jelas dan penempatan gambar serta tabel dalam handout, 3) fisiki memiliki kategori valid karena memiliki tambahan dari validator yaitu cover pada handout harus lebih menarik, dan 4) manfaat handout memiliki kategori valid.

Tabel 1. Rangkuman Hasil Validasi Handout

\begin{tabular}{cllc}
\hline No. & Aspek Penilaian & $\overline{\boldsymbol{X}}$ & Ket. \\
\hline 1. & Format & 3,2 & Valid \\
2. & Bahasa dan tulisan & 3,5 & Sangat valid \\
3. & Isi handout & 3,6 & Sangat valid \\
4. & Ilustrasi & 3,4 & Valid \\
5. & Fisik & 3,4 & Valid \\
6. & Manfaat handout & 3,4 & Valid \\
\hline & Rata-rata total & 3,4 & valid \\
\hline
\end{tabular}

Sedangkan pengembangan handout yang dikembangkan yang berada pada kategori sangat valid yaitu 1) bahasa dan tulisan memiliki kategori sangat valid karena materi handout yang mudah dimengerti dan tata bahasa yang digunakan dalam materi sudah sesuai dengan EYD dan 2) isi handout memiliki kategori sangat valid hal ini sesuai dengan materi dalam handout IPA terpadu tipe webbed mencakup kajian materi fisika, kimia, dan biologi, namun masih ada beberapa saran yang harus diperbaiki yaitu melengkapi materi dalam handout. Setelah dilakukan revisi terhadap kekurangan-kekurangan yang telah ditemukan maka hasil validasi handout tersebut dapat digunakan.

Hal ini sesuai dengan penelitian Faizah (2014) menyatakan bahwa pengembangan handout yang telah dikembangkan, dengan hasil penilaian validator termasuk dalam kategori baik dan dapat digunakan sebagai alternatif pembelajaran di sekolah. Dari penelitian tersebut menekankan bahwa penggunaan handout dapat digunakan di sekolah dan hal ini sama diungkapkan oleh (Putri, Ismono and Rosdiana, 2013) bahwa perangkat pembelajaran yang dikembangkan memiliki kriteria sangat valid dan validasi keterbacaan buku peserta didik memperoleh sangat kuat. Selain dilakukan validasi handout, validasi intrumen tes hasil belajar juga dilakukan. Hasil validasi disajikan pada Tabel 2.

Berdasarkan pada Tabel 2 penilaian validator diperoleh skor rata-rata 3,3 dengan kriteria valid. Hasil tersebut menunjukkan bahwa instrumen hasil belajar dapat digunakan dalam tahap uji coba pada penilitian pengembangan ini. Hasil handout yang telah dikembangkan diuji coba secara terbatas di SMP Negeri 2 Majene kelas VIIIA. Hasil uji coba penggunaan handout dalam pembelajaran IPA disajikan pada Tabel 3.

Pada tabel 3 tampak bahwa sebanyak 53,5\% peserta didik memiliki N-gain hasil belajar yang berada pada kategori tinggi dan sisanya sebanyak $46,5 \%$ peserta didik memiliki $\mathrm{N}$-gain hasil belajar pada kategori sedang. Analisis N-gain telah memberikan indikasi bahwa terjadi peningkatan hasil belajar peserta didik. Penggunaan handout IPA terpadu tipe webbed berbasis kontekstual dalam menyajikan tema makanan secara sederhana membantu peserta didik dalam belajar. Materi yang 
terdapat dalam tema makanan dapat disampaikan dengan baik kepada peserta didik melalui handout IPA terpadu tipe webbed berbasis kontekstual dan membuat peserta didik memahami tema makanan dengan lebih mudah. Hal ini sesuai dengan penelitian Kurt and Pehlivan (2013) yang menyatakan bahwa dengan memadukan materi secara terpadu memilki efek positif terhadap peserta didik. Penelitian tersebut menekankan bahwa dengan adanya handout IPA terpadu maka akan memberikan efek positif bagi peserta didik. Penelitian tersebut menyimpulkan bahwa dengan adanya handout IPA terpadu maka akan memberikan efek positif seperti meningkatkan hasil belajar peserta didik. Dan hasil penelitian Jake (2011) menyatakan bahwa dengan menggunakan handout dalam proses pembelajaran akan lebih efisien dan dan peserta didik akan lebih aktif dalam proses pembelajaran. Deksripsi pencapaian indikator hasil belajar peserta didik disajikan pada Tabel 4

Pada Tabel 4 terlihat bahwa persentase pencapaian yang sangat tinggi yaitu indikator 3 menyebutkan sumber-sumber energi dengan persentase pencapaian yaitu $89,29 \%$, indikator 7 menjelaskan proses pencernaan dalam tubuh manusia dengan persentase $92,89 \%$, indikator 8 menjelaskan keterkaitan sistem pencernaan dengan sistem pernapasan, peredaran darah dan penggunaan energi makanan dengan persentase $89,29 \%$. Hal ini dikarenakan dengan penggunaan bantuan handout IPA terpadu yang memiliki materi fisika, kimia, dan biologi saling berkaitan atau terpadu dalam satu tema maka dalam proses pembelajaran membuat peserta didik lebih memahami materi dengan baik.

Tabel 2. Rangkuman Hasil Validasi Instrumen Hasil Belajar

\begin{tabular}{cllc}
\hline No. & Aspek Penilaian & $\overline{\boldsymbol{X}}$ & Keterangan \\
\hline 1. & Materi & 3 & Valid \\
2. & Konstruksi & 3,5 & Sangat valid \\
3. & Bahasa & 3,7 & Sangat valid \\
4. & Waktu & 3 & Valid \\
\hline & Rat-rata total & 3,3 & valid \\
\hline
\end{tabular}

Tabel 3. Persentase $\mathrm{N}$-gain Hasil Penelitian

\begin{tabular}{lcc}
\hline \multicolumn{1}{c}{ Aspek Penilaian } & Jumlah & Persentase (\%) \\
\hline Tinggi & 15 & $53,5 \%$ \\
Sedang & 13 & $46,5 \%$ \\
Rendah & 0 & $0,0 \%$ \\
\hline Jumlah & $\mathbf{8 2}$ & $\mathbf{1 0 0} \%$ \\
\hline
\end{tabular}


Tabel 4. Persentase Pencapaian Hasil Belajar Peserta Didik Tiap Indikator

\begin{tabular}{|c|c|c|c|}
\hline No. & Indikator & Nomor Soal & Pencapaian Persentase (\%) \\
\hline 1. & Mengidentifikasi peranan energi dalam kehidupan & 10,1 & 79,46 \\
\hline 2. & $\begin{array}{l}\text { Menjelaskan bentuk energi yang berhubungan } \\
\text { dengan makanan }\end{array}$ & 9 & 85,71 \\
\hline 3. & Menyebutkan sumber-sumber energi & 17 & 89,28 \\
\hline 4. & Menjelaskan sistem pencernaan dalam tubuh & 7 & 64,28 \\
\hline 5. & $\begin{array}{l}\text { Menjelaskan zat gizi yang terkandung di dalam } \\
\text { makanan }\end{array}$ & 2,15 & 87,49 \\
\hline 6. & $\begin{array}{l}\text { Menjelaskan fungs-fungsi organ sistem pencernaan } \\
\text { pada manusia }\end{array}$ & 4 & 64,28 \\
\hline 7. & Menjelaskan proses pencernaan dalam tubuh manusia & 11 & 92,86 \\
\hline 8. & $\begin{array}{l}\text { Menjelaskan keterkaitan sistem pencernaan dengan } \\
\text { sistem pernafasan, sistem peredaran darah, dan } \\
\text { penggunaan energi makanan }\end{array}$ & 14 & 89,28 \\
\hline 9. & $\begin{array}{l}\text { Menyebutkan macam-macam zat aditif dalam } \\
\text { makanan }\end{array}$ & $12,16,8$ & 86,9 \\
\hline 10. & $\begin{array}{l}\text { Mengidentifikasi pewarna alami dan buatan dalam } \\
\text { makanan }\end{array}$ & 5,6 & 89,28 \\
\hline 11. & Menyebutkan dampak zat aditif bagi kesehatan tubuh & 3,13 & 78,57 \\
\hline \multicolumn{3}{|c|}{ Rata-rata total } & 82,65 \\
\hline
\end{tabular}

Indikator persentase pencapaian yang rendah yaitu indikator 4 menjelaskan sistem pencernaan dalam tubuh dan indikator 6 adalah menjelaskan fungsi organ-organ pencernaan pada manusia dengan persentase $64.29 \%$. Hal ini disebabkan karena pada handout kurang menjelaskan fungsi organ-organ sistem pencernaan dalam tubuh dan hanya sebagian organ yang memiliki fungsi yang terdapat pada handout sehingga peserta didik kurang memahami materi tersebut. Tetapi secara keseluruhan nilai persentase pencapaian hasil belajar peserta didik yaitu $82,65 \%$.

Hal tersebut menjadi salah satu faktor dalam memudahkan pemahaman konsep peserta didik sehingga hasil belajar peserta didik meningkat. Hal ini sesuai hasil penelitian sebelumnya yang telah dilakukan oleh (Suwaryantini, Sulastri and Suarni, 2014) bahwa hasil belajar peserta didik lebih meningkat dengan menggunakan media melalui model pembelajaran IPA terpadu tipe webbed dan ditambahkan pula (Taufiq, Dewi and Widiyatmoko, 2014) menyimpulkan bahwa kualitas pembelajaran dan hasil belajar berpengaruh terhadap pembentukan sikap.

Berdasarkan uraian diatas, hasil penelitian menunjukkan bahwa dengan adanya handout maka kualitas pembelajaran semakin tinggi dan dan selama proses pembelajaran peserta didik juga terlihat sangat tertarik dengan penggunaan handout terutama dalam memahami konsep-konsep dalam tema makanan. Hal ini juga sesuai dengan penilitian (Budimah, Herpratiwi and Rosidin, 2014) yaitu dengan adanya bahan ajar cetak kebutuhan peserta didik dalam belajar lebih efektif sehingga meningkatkan hasil belajar peserta didik.

Tabel 5. Rangkuman Hasil Respon Peserta Didik

\begin{tabular}{|c|c|c|c|}
\hline No. & Aspek penilaian & $\bar{x}$ & Keterangan \\
\hline 1 & Kelayakan isi Handout & 87 & Sangat positif \\
\hline 2 & Tampilan fisik handout & 88 & Sangat positif \\
\hline 3 & Bahasa & 87 & Sangat positif \\
\hline \multirow[t]{2}{*}{4} & Penerapan handout. & 93 & Sangat positif \\
\hline & Rata-rata total & 89 & Sangat positif \\
\hline
\end{tabular}


Hasil analisis tersebut ditunjukan dari rata-rata persentase respon peserta didik yaitu 89 yang berada dalam kategori 81,00 - 100 dengan interpretasi yang sangat positif.

Handout adalah bahan pembelajaran yang sangat ringkas. Bahan ini bersumber dari beberapa literatur yang relevan terhadap kompetensi dasar dan materi pokok. Bahan ajar ini diberikan kepada peserta didik guna memudahkan mereka saat mengikuti proses pembelajaran (Prastowo, 2014).

Kelebihan dari handout IPA terpadu adalah 1) Sesuai tuntutan kurikulum 2013 yang menekankan pembelajaran IPA terpadu dalam pembelajaran fisika, kimia, dan biologi yang dalam pelaksanaannya tidak lagi terpisah-pisah melainkan menjadi satu kesatuan, 2) Isi materi pada handout yang kontekstual sehingga membangun pengetahuan peserta didik, dan 3) Handout yang dikembangkan merupakan bahan ajar cetak mudah digunakan peserta didik, dan 4) penggunaan handout dalam proses pembelajaran akan lebih efisien. Hal ini sesuai dengan hasil penilitian Nelson (2013) yaitu dengan menggunakan handout dalam proses pembelajaran peserta didik tidak mencatat lagi sehingga memiliki waktu yang lebih efisien Dan hasil penelitian Jake (2011) menyatakan bahwa dengan menggunakan handout dalam proses pembelajaran akan lebih efisien dan peserta didik akan lebih aktif dalam proses pembelajaran.

Berdasarkan hasil validasi yang telah dilakukan pada pengembangan handout yang di kembangkan berada pada kategori valid dan sangat valid. Hal ini dapat dilihat dari 5 aspek kategori valid yang terdiri dari 1) format yang memiliki kategori valid dengan beberapa masukan oleh validator yaitu setiap KD harus memiliki indikator secara lengkap, 2) ilustrasi dalam handout memiliki kategori valid, dengan perbaikan yaitu perbaikan gambar yang kurang jelas dan penempatan gambar serta tabel dalam handout, 3) fisiki memiliki kategori valid karena memiliki tambahan dari validator yaitu cover pada handout harus lebih menarik, dan 4) manfaat handout memiliki kategori valid.

Pengembangan handout yang dikembangkan yang berada pada kategori sangat valid yaitu 1) bahasa dan tulisan memiliki kategori sangat valid karena materi handout yang mudah dimengerti dan tata bahasa yang digunakan dalam materi sudah sesuai dengan EYD dan 2) isi handout memiliki kategori sangat valid hal ini sesuai dengan materi dalam handout IPA terpadu tipe webbed mencakup kajian materi fisika, kimia, dan biologi, namun masih ada beberapa saran yang harus diperbaiki yaitu melengkapi materi dalam handout. Setelah dilakukan revisi terhadap kekurangankekurangan yang telah ditemukan maka hasil validasi handout tersebut dapat digunakan.

Hasil analisis persentase pencapaian hasil belajar peserta didik tiap indikator yang sangat tinggi yaitu indikator 3 menyebutkan sumber-sumber energi dengan persentase pencapaian yaitu $89,29 \%$, indikator 7 menjelaskan proses pencernaan dalam tubuh manusia dengan persentase 92,89 $\%$, indikator 8 menjelaskan keterkaitan sistem pencernaan dengan sistem pernapasan, peredaran darah dan penggunaan energi makanan dengan persentase $89,29 \%$. Hal ini dikarenakan dengan penggunaan handout IPA terpadu yang memiliki materi fisika, kimia, dan biologi saling berkaitan atau terpadu dalam satu tema maka dalam proses pembelajaran membuat peserta didik lebih memahami materi dengan baik, sedangkan Indikator persentase pencapaian yang rendah yaitu indikator 4 menjelaskan sistem pencernaan dalam tubuh dan indikator 6 adalah menjelaskan fungsi organ-organ pencernaan pada manusia dengan persentase $64.29 \%$. Hal ini disebabkan karena pada handout kurang menjelaskan fungsi organ-organ sistem pencernaan dalam tubuh dan hanya sebagian organ yang memiliki fungsi yang terdapat pada handout sehingga peserta didik kurang memahami materi tersebut. Tetapi secara keseluruhan nilai persentase pencapaian hasil belajar peserta didik yaitu $82,65 \%$.

Hal tersebut menjadi salah satu faktor dalam memudahkan pemahaman konsep peserta didik dan pembentukan sikap dalam memahami materi IPA terpadu sehingga hasil belajar peserta didik meningkat. Hal ini sesuai hasil penelitian sebelumnya yang telah dilakukan oleh Taufiq, Dewi and Widiyatmoko (2014) menyimpulkan bahwa kualitas pembelajaran dan hasil belajar berpengaruh terhadap pembentukan sikap sehingga meningkatkan hasil belajar peserta didik. 


\section{KESIMPULAN}

Berdasarkan hasil penelitian yang telah dilakukan pada peserta didik kelas VIIIA SMPN 2 Majene maka dapat diambil kesimpulan sebagai berikut:

1) Kualitas handout IPA terpadu tipe webbed berbasis kontekstual pada tema makanan adalah valid.

2) Respon peserta didik dan pendidik terhadap pengembangan handout IPA terpadu tipe webbed berbasis kontekstual pada tema makanan adalah sangat positif.

3) N-gain hasil belajar peserta didik yang dibelajarkan dengan menggunakan handout pembelajaran IPA terpadu tipe webbed dengan persentase penilaian $53,5 \%$ yang menunjukkan peningkatan berada dalam kategori tinggi.

\section{DAFTAR PUSTAKA}

Akhtar, A., \& Akbar. R. A. (2011). Use of Media for Effective Instruction its Importance: Some Consideration. Jurnal of Elementary Education, Vol 18 (1-2).

Arikunto, S. (2006). Prosedur Penelitian: Suatu Pendekatan Praktik. Jakarta: Rineka Cipta.

Daryanto., \& Dwicahyono, A. (2014). Pengembangan Perangkat Pembelajaran (Silabus, RPP, PHB, Bahan Ajar). Yogyakarta: Gava Media.

Depdiknas. (2008). Panduan Pengembangan Bahan Ajar. Jakarta: Depdiknas.

Depdiknas. (2013). Panduan Pengembangan Pembelajaran IPA Terpadu. Jakarta: Depdiknas.

Faizah, A., Kurniawan, E, S., \& Nurhadi. (2014). Pengembangan Handout Fisika Berbasis Guided Note Taking Guna Meningkatkan Motivasi Belajar Peserta Didik Kelas X Di SMA Negeri 3 Purworejo Tahun Pelajaran 2013/2014. Radiasi, Vol. 5 No. 2.

Fauzi., U. (2015). Desain Penelitian Pengembangan Bahan Ajar IPA Terpadu Tema Cahaya dan Warna untuk Pembelajaran IPA SMP. SNIPS. Bandung: Indonesia.

Fogarty, R. (1991). How to Integrate the Curricula. Illinois, IRI/sky publishing inc.

Hadisubroto, H. (2000). Pembelajaran Terpadu Materi Pokok PGSD. Jakarta: Universitas Terbuka.

Hake, R. (1991). Analzing Change/Gain Scare. http://www.physis.indiana.edu/sdi/analyzingchangegain.pdf. Makassar. Diakses pada tanggal 28 Juli 2016.

Hobri. (2010). Metodologi Penelitian Pengembangan. Jember: Pena Salsabila.

Husna, H., N. (2015). Pengembangan Bahan Ajar Berbasis Pembelajaran IPA Terpadu Model Webbed dengan Tema Gunung Berapi. SNIPS. Bandung: Indonesia.

Jake, Keith. (2011). Overhauling Technical Handouts for Active Student Participation: A Model for Improving Lecture Effeciency and Increasing Attendance. International Journal of Teaching and Learning in Higher Education. Vol. 23 No. 1.

Jaya, I, M,. Sadia, I, W,. \& Arnyana, I,. B,. P. (2014). Pengembangan Perangkat Pembelajaran Biologi Bermuatan Pendidikan Karakter Dengan Setting Guided Inquiri Untuk Meningkatkan Karakter dan Hasil Belajar Siswa SMP. E-Journal Program Pascasarjana Universitas Pendidikan Ganesha. Vol. 4

Kurniawati, A,. Suliyanah,. \& Qosyim. A. (2013). Pengembangan Bahan IPA Terpadu Tema Letusan Gunung Berapi Kelas VII di SMP Negeri 1 Kamal. Jurnal Pendidikan Sains e-Pensa. Vol. 1 No. 2.

Kurt, K., W., \& Pehlivan, M. (2013). Integrated Programs for Science and Mathematics: Review of Related Literature. International Journal of Education in Mathematics, Science and Technology. Vol. 1 No. 2.

Lepiyanto, A., \& Pratiwi, D. (2015). Pengembangan Bahan Ajar Berbasis Kontekstual pada Matakuliah Biologi Umum. Jurnal Pendidikan Biologi Universitas Muhammadiyah Metro. Vol 1 No. 6.

Majid, A. (2008). Perencanaan Pembelajaran. Bandung: PT Remaja Rosdakarya. 
Nelson, E., W., Eigsti, H., Hammerich, A., \& Ellison, N. (2013). Influence of Presentation Handout Completeness on Student in a Physical Therapy Curriculum. Journal of the Scholarship of Teaching and Learning. Vol. 13 No. 3.

Nuh, M. (2014). Ilmu Pengetahuan Alam Kelas VII Semester 2. Jakarta: Kemdikbud.

Nuh, M. (2014). Ilmu Pengetahuan Alam Kelas VIII Semester 1. Jakarta: Kemdikbud.

Nurdin. (2007). Model Pembelajaran Matematika Untuk Menumbuhkan Kemampuan Metakognitif Untuk Menguasai Bahan Ajar. Surabaya: Unesa.

Oktamagia, D, W., Fauzi, A., \& Hidayati. (2013). Pengaruh Pembelajaran Terpadu Tipe Connected Terhadap Hasil Belajar IPA Fisika Pada Materi Cahaya Dan Alat Optik di Kelas VIII SMPN 1 Sungai Tarab. Pillar Of Physics Education. Vol. 2.

Pantiwati, Y., Atok, M., H., \& Tuti, K. (2014).Triple Approach Instruction to Improve Learning Process Outcome of Intergrated Science Subject. Journal of Education and Practicel. Vol. 5 No. 38 .

Prastowo, A. (2014). Pengembangan Bahan Ajar Tematik. Jakarta: Prenadamedia Group.

Prastowo, A. (2015). Menyusun Rencana Pelaksanaan Pembelajaran (RPP) Tematik Terpadu. Jakarta: Prenadamedia Group.

\section{A. Fitriani Suryadi \\ Dosen Program Studi Pendidikan Biologi STKIP Yapti Turatea Jeneponto, aktif melakukan penelitian pada bidang Pendidikan, dapat dihubungi melalui pos-el: a.fitrianisuryadi3o@gmail.com.}

\section{Sudarto}

Dosen Program Studi Pendidikan IPA FMIPA UNM, aktif melakukan penelitian pada bidang Pendidikan IPA.

\section{Ramlawati}

Dosen Program Studi Pendidikan IPA FMIPA UNM, aktif melakukan penelitian pada bidang Pendidikan IPA. 